\title{
Marketing Capabilities Model for Pharmaceutical Business in Thailand
}

\section{Chayanan Kerdpitak and Napassorn Kerdpitak}

Collage of Innovation and Management, Suan Sunandha Rajabhat University, Thailand

Email: chayanan.ke@ssur.ac.th

Article History: Received: 10 November 2020; Revised 12 January 2021; Accepted: 27 January 2021; Published online: 5 April 2021

\begin{abstract}
There are few studies in the past which have worked on evaluating the capability of the marketing teams as the means of generating an effective strategy in terms of competiveness in the market and creation of advantage that is held by a firm in the market. However, the aim behind conducting this research is to find an effective mechanism or formula to have better performance in the export field, internationalization success, and marketing communication mainly by analyzing the role that is played by the marketing capabilities. Moreover, the researcher has mapped the relationship which exists between the capabilities and communication with the mediating impact of competitive strategy has also been evaluated in this research paper. The population of this study was the employees of different pharmaceutical firms of Thailand, and the sample was 300 entrepreneur of pharmaceutical business. The results and findings show that the impact of marketing capabilities has been favorable to enhance the export performance of the sector. Furthermore, the findings also indicate that the mediating variable of competitive strategy also positively mediates the relationship that exists between the variables of marketing capabilities and marketing communication. This study has significant implications on MC and export performance.
\end{abstract}

Keywords: Competitive Strategy, Marketing capabilities, Internationalization performance, marketing communication, Export venture performance

\section{Introduction}

As the trend for globalization is increasing worldwide, many firms are attempting to take advantage of international trading options (Martin, Javalgi, \& Ciravegna, 2020). These firms aim to achieve a competitive advantage by using the human capabilities and other resources available to them for doing trade on an international basis. Hence, there is whole bunch of such firms that undergo rapid internationalization. This concept was initially conceived by Rennie (1993) and it marks the ability to internationalize has become vital for the growth and survival of the firms (Joensuu-Salo, Sorama, Viljamaa, \& Varamäki, 2018; Sun, Price, \& Ding, 2019).

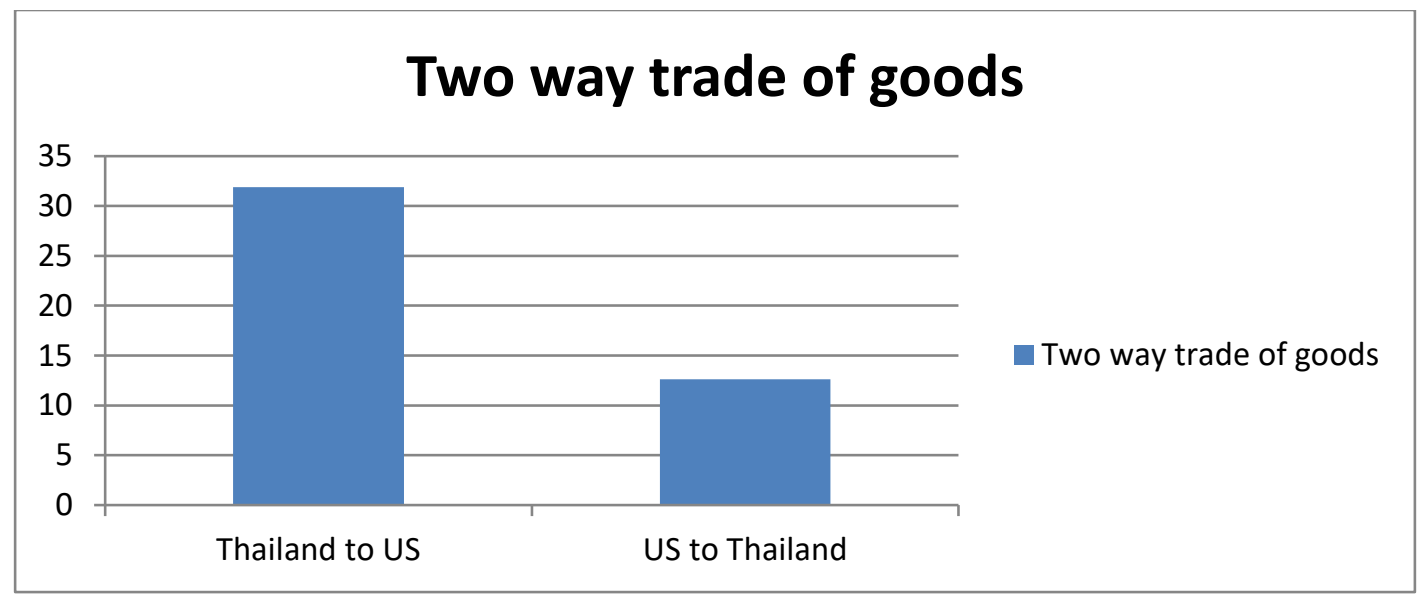

Graph 1.1: Two way trade of goods 
In addition to this, the marketing communication can be recognized as a capability which is specific to the firms that is embedded in the daily routines and practices of the organization (Lin and $\mathrm{Wu}, 2014$ ). Based on the RBV, a capability refers to performing an organizational function at an acceptable level and way which leads to numerous advantages (Helfat et al., 2009; Martin \& Javalgi, 2019; Rua, França, $\&$ Ortiz, 2018). This study is focused on the pharmaceutical firms of Thailand, which is the $20^{\text {th }}$ largest export destination and the $2^{\text {nd }}$ largest economy in ASEAN.

\begin{tabular}{ll}
\hline & USD billion \\
\hline Export worth of goods & 249.8 billion \\
Exports with US & 44.5 \\
GDP & 529
\end{tabular}

Table 1.1: Thailand economy statistics

Literature is available on the marketing capabilities and communication but empirical studies regarding their interaction to gain competitive advantage are limited (Batra \& Keller, 2016; Martin et al., 2020; Morgan, Katsikeas, \& Vorhies, 2012), however this study will be the first of its kind, to the best of the knowledge of the author, that has integrated these variables from the perspective of RBV for the international ventures, especially in the pharmaceutical firms in Thailand, making it worth considering as a future research topic. The researcher aimed to fill this contextual gap.

The major aim of the study is to explore the effect of marketing capabilities on performance of the pharmaceutical firms in Thailand. Specifically, this study has the following research objectives:

- To find out the effect of that the Marketing capabilities exert on Export venture performance

- To examine the effect of Marketing capabilities exert on Internationalization performance

- To evaluate the effect of Marketing capabilities on marketing communication

- To determine the mediating effect of Competitive strategy on these relationships.

This study contributes to the knowledge volume by conducting investigation into the underlying mechanism of Competitive strategy as the mediator in the above mentioned relationships. This study has several implications of practical nature that are useful for the managers of firm who can recognize the value of proper marketing capabilities that can aid in building competitive advantage for superior performance in export venturing, internationalization and communications.

This paper is arranged in the following way. Starting with Introduction, an in depth review of literature of the variables under consideration is built up with the research framework drawn out of it. The next section describes the research methodology which will be applied to test the deduced hypothesis. The fourth section will present the findings of the study by analyzing them statistically. The last section presents the discussion and draws conclusion on the basis of findings. The paper ends with highlighting the research limitations and theoretical \& managerial implications.

\section{Literature review}

\subsection{Theoretical background}

This study is based on the RBV theory, which states that every organization possesses resources and capabilities that can be efficiently utilized by them to achieve their goals efficiently.

\subsection{Effect of Marketing capabilities on export venture performance}

The international marketing literature has explained the importance of MC that aids the firms to develop effective marketing strategy and implement them in export venture operations for superior performance (Morgan et al., 2012; Zou, Fang, \& Zhao, 2003). In the context of this research, marketing capabilities can be defined as the process that is used to integrate and apply a firm's knowledge, its resources and its skills to achieve the needs that are related to the market. These capabilities provide the intentional venturing firms with value creation and addition for the purpose of meeting with the needs and demands of the markets which have become highly competitive (Martin, Javalgi, \& Cavusgil, 2017; Martin \& Javalgi, 2019). Hence, they can serve as good drivers of market related resources used to respond to the 
dynamic changes and challenges of the business (Moorman \& Day, 2016). The literature on marketing capabilities has proved that it leads to superior financial, strategic and product performance in various industrial sectors (Martin et al., 2020; Murray, Gao, \& Kotabe, 2011; Vorhies \& Morgan, 2005). This implies that MC is directly related to EVP. Hence, the hypothesis:

H1: There is a significant relationship between marketing capabilities and export venture performance 2.3 Effect of Marketing capabilities on internationalization performance

Firms that have the capabilities of developing new products, service and distribution are capable of developing and offering new products \& services with effective distribution strategy so that the firm can be differentiated from its competitors and cost leadership can be achieved and meet the needs and demands of international consumers, hence attaining international performance. Studies conducted by (Freixanet, 2012; Jin, Jung, \& Jeong, 2018; Joensuu-Salo et al., 2018; Khurshid, Khan, Al-Aali, \& Lim, 2013; Martin et al., 2020; Mashahadi, Ahmad, \& Mohamad, 2016; Ren, Eisingerich, \& Tsai, 2015; Sun et al., 2019; Zeng, Xie, Tam, \& Wan, 2009) have shown that the marketing capabilities can lead to improved internationalization performance. Hence, the hypothesis:

H2: Marketing capabilities is significantly linked to Internationalization performance

\subsection{Effect of Marketing capabilities on Marketing communication}

Marketing capabilities are the abilities of a firm that can be used to generate and disseminate information for the purpose of developing proper responses for the current and future needs of the consumers in the light of the changing dynamics and competitiveness in the market (Martin et al., 2020). For the INVs that have interactions in the foreign markets, the marketing communication enables firms interacting in foreign markets to manage the value perceptions of the export customers. With this approach, they are able to stimulate their customers in building positive perception about their products and a differentiated brand image. Marketing communication stresses on a two-way communication process so that the interactivity of the customer \& competitors with the broader marketing environment could be established (Kumar, Keller, \& Lemon, 2016). Study by (Martin et al., 2020)has proved that $\mathrm{MC}$ of International ventures have direct relations with the marketing communication process using effective advertising and promotion. This implies that MC has direct links with Marketing Communication. Hence, the hypothesis:

H3: Marketing capabilities is significantly linked to MC.

\subsection{Mediation of Competitive Strategy}

Competitive strategy is defined as the strategies of a firm that allow it to decide the actions and plans which can be carried out for the purpose of achieving superior performance of export ventures. Globalization and technological advancements have forced the international ventures to compete in ways that require accurate strategic decisions (Leonidou, Palihawadana, \& Theodosiou, 2011). So, for gaining a competitive advantage, firms need to combine their resources and deploy their capabilities in dynamic processes of rapid and appropriate progress (Knight \& Liesch, 2016; Kraaijenbrink, Spender, \& Groen, 2010; Spanos \& Lioukas, 2001). Early scholars have established positive links of competitive strategy and business performance (Furrer, Sudharshan, Thomas, \& Alexandre, 2008; Kaleka, 2011). Previous researches have reported that a a significant relationship between the MCs and competitive strategy exists, owing to their ability to implement effective response to major rival firms strategies in a timely manner. Study conducted by has shown that competitive strategy of firm pursues is positively related to the EVP in the export market where the firm competes. MCs contribute to the competitive strategies of a firm which are in alignment of the requirements that are held by the international marketplace (Rua et al., 2018; Tan \& Sousa, 2015; Weerawardena \& Mavondo, 2011). Marketing capabilities gives the firm potential to make decision regarding the selection of competitive strategy among the options that is more likely to be successful in the international market (Efrat, Hughes, Nemkova, Souchon, \& Sy-Changco, 2018; Morgan et al., 2012). Hence, firms with MC can generate a competitive advantage (Martin et al., 2020). So, this study can investigate the impact that competitive strategy has and can hypothesize:

H4a: Competitive strategy has a significant mediation the effect between the marketing capabilities and Export venture performance. 
H4b: Competitive strategy has a significant mediation the effect between the marketing capabilities and Internationalization performance.

H4c: Competitive strategy has a significant mediation the effect between the marketing capabilities and Marketing communication.

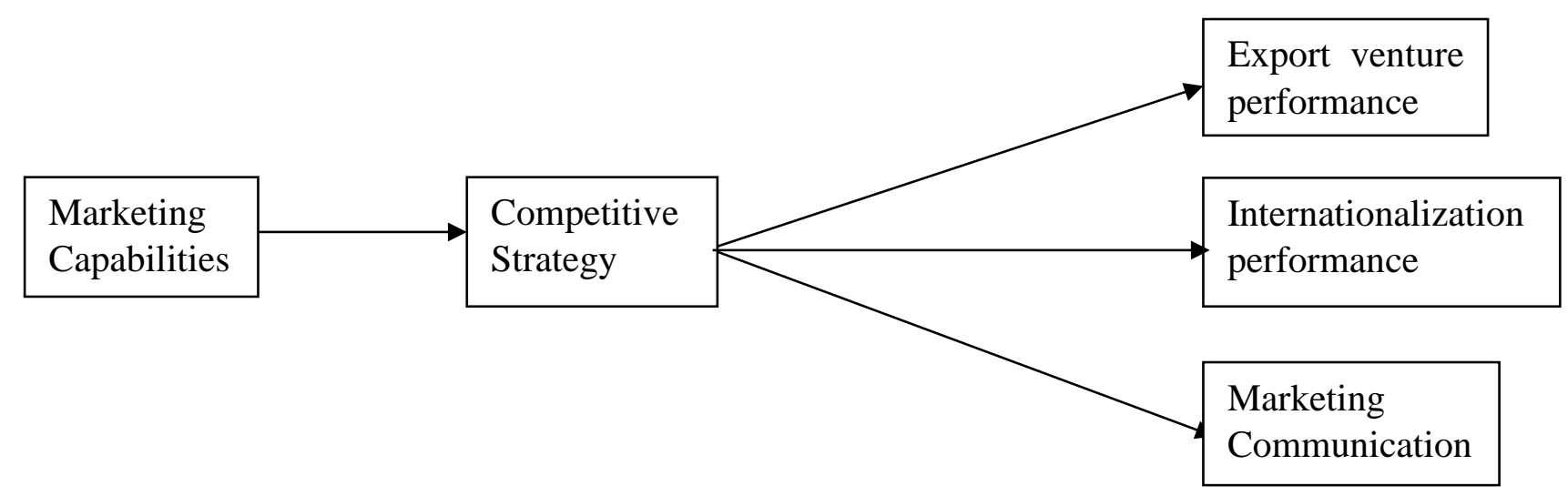

Figure 1.2: Research framework

\section{Methods}

\subsection{Sample Characteristics}

A questionnaire based survey design was followed for this study. The method of snowball sampling was used as the permission to visit and obtain information from pharmaceutical companies is difficult and also the staff is deliriously busy. The respondents were provided with a brief introduction and then the questionnaire was distributed among the participants. The respondents were assured that their identities will be kept anonymous. The total number of questionnaires distributed were 320 . Although only 300 out of these were fit for use 10 were misplaced, 10 were discarded due to presence of missing values and the remaining 20 had missing values.

\subsection{Measures}

The scale items were selected after extensive literature review. In order to confirm the content validity of scale items two academicians were asked to review the construct. Then the questionnaire was pretested on $50 \mathrm{MBA}$ students, minor changes were made in the construct following the advices of both. The advice of Campbell, Brislin, Stewart, and Werner (1970) was followed and the forward and back translation method was used. All scale items have been measured on a five point Likert scale, ranging from " $1=$ strongly disagree" to " $5=$ strongly agree".

\subsubsection{Marketing capabilities}

Marketing capabilities was measured on three dimensions; distribution, service and new product development. The items for measuring this construct were adapted from the studies of Zou et al. (2003) and Katsikeas, Paparoidamis, and Katsikea (2004). The items for the construct were modified according to requirements of the present study. A sample item is "Delivering high quality after-sales service".

\subsubsection{Competitive strategy}

Competitive strategy, the latent variable was measured on the basis of three dimensions. These were market differentiation, cost leadership and delivery differentiation. Cost leadership is a measure of the degree to which lower prices than competitors are offered to customers, the items were developed from the studies of Styles and Ambler (1994) and Aulakh, Kotabe, and Teegen (2000). The other dimesnions were adapted from the studies of Menguc, Auh, and Shih (2007) and Spanos and Lioukas (2001). A sample item is "Invest in marketing communications to build brand awareness" and "tightly control export venture selling and promotion expense"

\subsubsection{Export venture performance}

Perceptual measures were used to measure export venture performance. The scales were adapted from the studies of Katsikeas, Leonidou, and Morgan (2000), Jaworski and Kohli (1993) and Moorman and Day (2016). The dimensions of effectiveness, adaptiveness and efficiency were used to measure the export venture performance. A sample item is "A large number of new product ideas have been made possible through technological breakthroughs in our industry". 


\subsubsection{Internationalization performance}

Internationalization performance was measured on the basis of the five item scale developed by Nummela, Saarenketo, and Puumalainen (2004). A sample item includes "We have achieve dour profitability objectives set for our internationalization over the last five years".

\subsubsection{Marketing communication}

The scale was developed from the studies of Zou et al. (2003). The scale was modified according to the requirements of the present study. A sample item is "Developing effective export advertising and promotion".

\section{Results}

\subsection{Demographics:}

The sample consisted of 300 respondents, out of these 48 percent were male and 52 percent were female. Thailand is particularly a country that demonstrates patriarchy in almost all sectors of its business industry therefore the disparity in gender division is observed. 79 percent of the sample is aged between 30 and 45. And the experience levels of more than half of the sample are spread between 3 and 8 years. The target employees were managers and assistants. Therefore the variation in ages and experience is observed.

\subsection{Descriptive Analysis}

Descriptive analysis is used to check the normality of data, agreeableness of respondents and to detect outliers. The mean values are approaching 4 which signifies the agreement of respondents with the statements of the variables. The normality of data is checked by observing the skewness values, all values fall within the prescribed range of $-1+1$, thus it can be proclaimed that data is distributed normally. . The Likert scale was used to record responses, referring to Table 1 it can be seen that the outliers were not present.

Table 1: Descriptive Statistics

\begin{tabular}{llllllll}
\hline & $\mathrm{N}$ & Minimum & Maximum & Mean & Std. Deviation & Skewness \\
\cline { 2 - 7 } & Statistic & Statistic & Statistic & Statistic & Statistic & Statistic & Std. Error \\
\hline MarkCap & 300 & 1.00 & 5.00 & 3.263 & 0.823 & -.191 & .120 \\
ComStr & 300 & 1.00 & 5.00 & 3.324 & 0.966 & -.366 & .120 \\
ExpPerf & 300 & 1.00 & 5.00 & 3.206 & 0.705 & -.282 & .120 \\
InterPerf & 300 & 1.00 & 5.00 & 3.565 & 0.625 & -.462 & .120 \\
MarkCom & 300 & 1.00 & 5.00 & 3.374 & 0.837 & -.477 & .120 \\
Valid N (listwise) & 300 & & & & & & \\
\hline
\end{tabular}

\subsection{KMO}

This test is used to measure of the adequacy of the sample. The KMO test checks for the sample adequacy and also analyzes the sample for relevancy among variables. The KMO value is greater than the threshold of 0.8 and the results of Bartlett's test are also significant. Thus the sample is adequate and unrelated, it is fit for factor analysis.

Table 2: KMO and Bartlett's Test

\begin{tabular}{lll}
\hline Kaiser-Meyer-Olkin Measure of Sampling Adequacy. & .894 \\
Bartlett's Test of Sphericity & Approx. Chi-Square & 4623.490 \\
& df & 105 \\
& Sig. & .000 \\
\hline
\end{tabular}

\section{4 factor analysis}

The component matrix is used to check the contribution of each individual scale item in the overall construct. All items have loadings more than 0.7 thus they are significant. 
Table 3: Rotated Component Matrix ${ }^{a}$

\begin{tabular}{|c|c|c|c|c|c|}
\hline & \multicolumn{5}{|c|}{ Component } \\
\hline & 1 & 2 & 3 & 4 & 5 \\
\hline$\overline{\mathrm{MC} 1}$ & & .839 & & & \\
\hline $\mathrm{MC} 2$ & & .895 & & & \\
\hline MC3 & & .854 & & & \\
\hline $\mathrm{CS} 1$ & & & & & .760 \\
\hline $\mathrm{CS} 2$ & & & & & .784 \\
\hline $\mathrm{CS} 3$ & & & & & .798 \\
\hline EP1 & .852 & & & & \\
\hline EP2 & .885 & & & & \\
\hline EP3 & .866 & & & & \\
\hline IP1 & & & .849 & & \\
\hline IP2 & & & .847 & & \\
\hline IP3 & & & .869 & & \\
\hline MCP1 & & & & .811 & \\
\hline MCP2 & & & & .813 & \\
\hline MCP3 & & & & .844 & \\
\hline
\end{tabular}

\subsection{Convergent and Discriminant Validity}

Table 4 presents the results for discriminant and convergent validity. MSV is less than AVE and selfcorrelation values are higher, therefore discriminant validity persists. Convergent validity is ensured on the basis of AVE and CR values. CR is the degree of internal consistency of the scale items, values greater than 0.7 ensure internal consistency. AVE values greater than 0.5 establish CV (Hassan, Hameed, Basheer, \& Ali, 2020; Iqbal \& Hameed, 2020). Thus as the results from table 4 confer both discriminant and convergent validity is present.

Table 4: Convergent and Discriminant Validity

\begin{tabular}{lllllllll}
\hline & CR & AVE & MSV & IP & MC & CS & EP & MCP \\
\hline IP & 0.903 & 0.756 & 0.378 & $\mathbf{0 . 8 6 9}$ & & & & \\
MC & 0.899 & 0.749 & 0.356 & 0.508 & $\mathbf{0 . 8 6 6}$ & & & \\
CS & 0.820 & 0.605 & 0.378 & 0.616 & 0.595 & $\mathbf{0 . 7 7 8}$ & & \\
EP & 0.919 & 0.791 & 0.492 & 0.305 & 0.326 & 0.351 & $\mathbf{0 . 8 8 8}$ & \\
MCP & 0.933 & 0.819 & 0.491 & 0.476 & 0.407 & 0.530 & 0.700 & $\mathbf{0 . 9 0 5}$ \\
\hline
\end{tabular}

\subsection{Model Fitness}

The model fitness is conferred by the CFA test. Results are evident in table 5 and figure 1 . The measures are in accordance with the defined threshold ranges therefore the model is fit.

Table 5: Confirmatory Factors Analysis

\begin{tabular}{lll}
\hline Indicators & Threshold range & Current values \\
\hline CMIN/DF & Less or equal 3 & 2.007 \\
GFI & Equal or greater .80 & 0.952 \\
CFI & Equal or greater .90 & 0.983 \\
IFI & Equal or greater .90 & 0.983 \\
RMSEA & Less or equal .08 & 0.051 \\
\hline
\end{tabular}




\section{Figure 1: CFA}

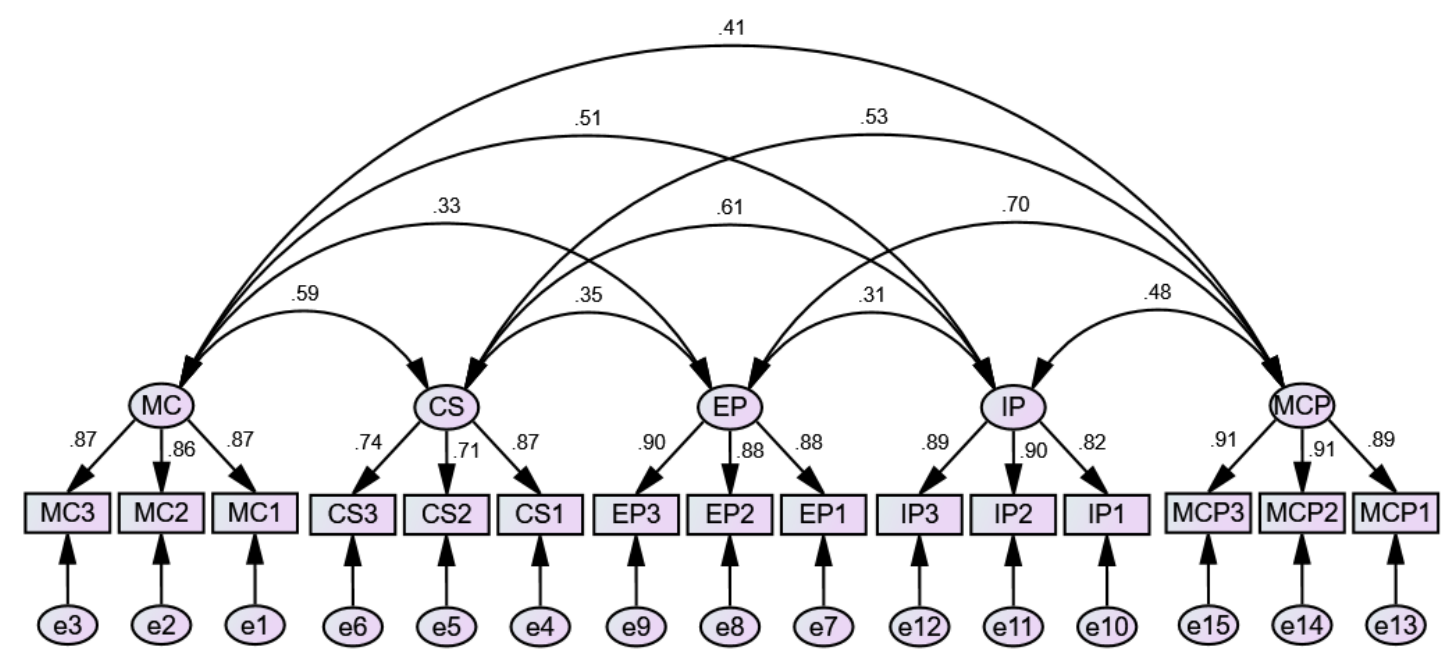

\subsection{SEM}

A unit change in market capitilization produces a direct effect of 20.66 percent on MarkCom, 23 percent on InterPerf and 21.70 percent on ExpPerf. The relationships are significant therefore the hypotheses are accepted. The mediation of ComStr produces effects of 36.31, 42.21 and 20.60 percent through markcap. the relationships are significant therefore the hypotheses are accepted.

Table 6: Structural Equation Modeling

\begin{tabular}{lll}
\hline Total Effect & MarkCap & ComStr \\
\hline ComStr & $.521^{* * *}$ & .000 \\
MarkCom & $.396^{* * *}$ & $.363^{* * *}$ \\
InterPerf & $.450^{* * *}$ & $.423^{* * *}$ \\
ExpPerf & $.325^{* * *}$ & $.206^{* *}$ \\
Direct effect & MarkCap & ComStr \\
ComStr & $.522^{* * *}$ & .000 \\
MarkCom & $.205^{* *}$ & $.363^{* * *}$ \\
InterPerf & $.230^{* *}$ & $.421^{* * *}$ \\
ExpPerf & $.217^{* *}$ & $.205^{* *}$ \\
Indirect Effect & MarkCap & ComStr \\
ComStr & .000 & .000 \\
MarkCom & $.189^{* *}$ & .000 \\
InterPerf & $.221^{* *}$ & .000 \\
ExpPerf & $.107^{*}$ & .000 \\
\hline
\end{tabular}




\section{Figure 2: SEM}

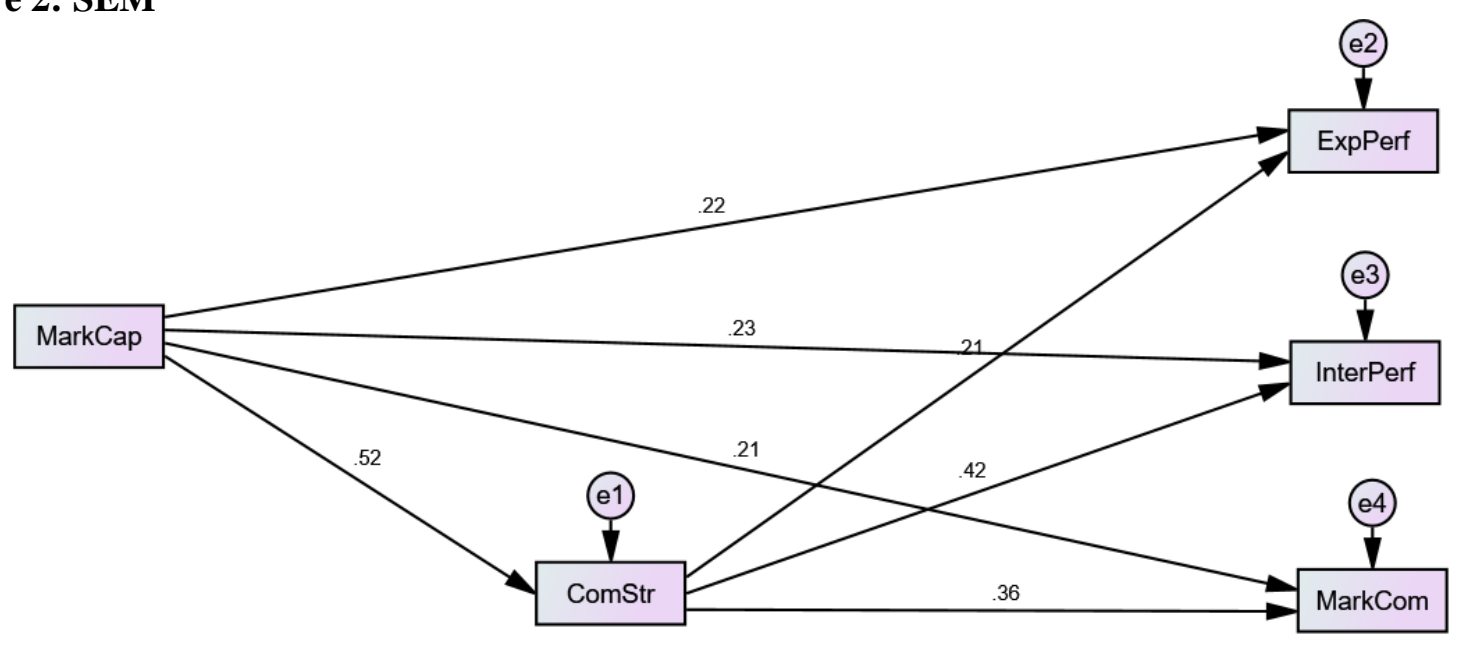

\section{Discussion}

The role of marketing capabilities is very significant in improving export performance as well as marketing communication because marketing capabilities are the capabilities of marketing team members that make some strong strategies about brands and products (Martin \& Javalgi, 2016). According to the first result of this research, it is revealed that the impact of the strategies of marketing has been positive and favorable in enhancing the performance of the export ventures. The marketing capabilities seize the difficult collection of data and knowledge that help firms to enhance the performance of export and it also offers the best way of working and tools that also play a crucial role in export performance (Morgan, Feng, \& Whitler, 2018). Therefore, the hypotheses related to the direct impact of MC on export performance has been supported and accepted. Marketing capabilities are an important enabler of marketing communication because $\mathrm{MC}$ can help a sector to sense and respond to changes in the market with the effective mechanism of communication, thus, the ability of marketing communication will be enhanced (Gregory, Ngo, \& Karavdic, 2019). That's why the hypotheses have been accepted and show positive results. Moreover, the results of this research also propose that the competitive strategy of the firm can enhance that the relation between MC and export venture performance and the hypotheses have been accepted.

\section{Conclusion}

The research paper shows that the most important keys to a successful business are Effective Marketing. With the proper usage of marketing strategy, the firms can achieve a level. The marketing capabilities as products, a strong link between partners, market sense, creates a positive effect. The study also shows that the possessions of marketing capabilities in the competitive strategy will lead to greater success and achievement internationally and the firms achieve a piece of knowledge through this experience of success to face the competitive atmosphere to counter the acts of the rivals. This data was gathered by 411 employees of the various firms to evaluate the results. Out of which the number of the male was 226 and the 185 were of the female.

\subsection{Implications and Limitations}

This study has a very positive influence and it is the gateway for further study and research to look for effective ways to enhance the product quality according to international standards. Cross-sectional nature is the first limitation of this research study which prohibits causal inference, so, it is proposed to future studies that they should conduct a study that is longitudinal. A future research study should be aimed at developing longitudinal information and data. Second, this study only considered one independent variable in his model, thus, it is recommended to further studies that they add other independent variables for more accurate results. 


\section{References}

[1]. Aulakh, P. S., Kotabe, M., \& Teegen, H. (2000). Export strategies and performance of firms from emerging economies: Evidence from Brazil, Chile, and Mexico. Academy of management Journal, 43(3), 342-361.

[2]. Batra, R., \& Keller, K. L. (2016). Integrating marketing communications: New findings, new lessons, and new ideas. Journal of Marketing, 80(6), 122-145.

[3]. Campbell, D., Brislin, R., Stewart, V., \& Werner, O. (1970). Back-translation and other translation techniques in cross-cultural research. International Journal of Psychology, 30, 681-692.

[4]. Efrat, K., Hughes, P., Nemkova, E., Souchon, A. L., \& Sy-Changco, J. (2018). Leveraging of Dynamic export capabilities for competitive advantage and performance consequences: Evidence from China. Journal of Business Research, 84, 114-124.

[5]. Freixanet, J. (2012). Export promotion programs: Their impact on companies' internationalization performance and competitiveness.

[6]. Furrer, O., Sudharshan, D., Thomas, H., \& Alexandre, M. T. (2008). Resource configurations, generic strategies, and firm performance. Journal of Strategy and Management.

[7]. Gregory, G. D., Ngo, L. V., \& Karavdic, M. (2019). Developing e-commerce marketing capabilities and efficiencies for enhanced performance in business-to-business export ventures. Industrial Marketing Management, 78, 146-157.

[8]. Hassan, S. G., Hameed, W. U., Basheer, M. F., \& Ali, J. (2020). Zakat compliance intention among selfemployed people: evidence from punjab, Pakistan. Al-Adwah. 34(2), 80-96.

[9]. Helfat, C. E., Finkelstein, S., Mitchell, W., Peteraf, M., Singh, H., Teece, D., \& Winter, S. G. (2009). Dynamic capabilities: Understanding strategic change in organizations: John Wiley \& Sons.

[10]. Iqbal, J., \& Hameed, W. U. (2020). Open Innovation Challenges and Coopetition-Based Open-Innovation Empirical Evidence From Malaysia Innovative Management and Business Practices in Asia (pp. 144-166): IGI Global.

[11]. Jaworski, B. J., \& Kohli, A. K. (1993). Market orientation: antecedents and consequences. Journal of marketing, 57(3), 53-70.

[12]. Jin, B., Jung, S., \& Jeong, S. W. (2018). Dimensional effects of Korean SME's entrepreneurial orientation on internationalization and performance: the mediating role of marketing capability. International Entrepreneurship and Management Journal, 14(1), 195-215.

[13]. Joensuu-Salo, S., Sorama, K., Viljamaa, A., \& Varamäki, E. (2018). Firm performance among internationalized SMEs: The interplay of market orientation, marketing capability and digitalization. Administrative Sciences, 8(3), 31.

[14]. Kaleka, A. (2011). When exporting manufacturers compete on the basis of service: Resources and marketing capabilities driving service advantage and performance. Journal of International Marketing, 19(1), 40-58.

[15]. Katsikeas, C. S., Leonidou, L. C., \& Morgan, N. A. (2000). Firm-level export performance assessment: review, evaluation, and development. Journal of the academy of marketing science, 28(4), 493-511.

[16]. Katsikeas, C. S., Paparoidamis, N. G., \& Katsikea, E. (2004). Supply source selection criteria: The impact of supplier performance on distributor performance. Industrial Marketing Management, 33(8), 755-764.

[17]. Khurshid, M., Khan, T., Al-Aali, A., \& Lim, J. (2013). Marketing capability and export performance: the moderating effect of export performance. South African Journal of Business Management, 44(3), 59-70.

[18]. Knight, G. A., \& Liesch, P. W. (2016). Internationalization: From incremental to born global. Journal of World Business, 51(1), 93-102.

[19]. Kraaijenbrink, J., Spender, J.-C., \& Groen, A. J. (2010). The resource-based view: A review and assessment of its critiques. Journal of Management, 36(1), 349-372.

[20]. Kumar, V., Keller, K. L., \& Lemon, K. N. (2016). Introduction to the special issue-Mapping the boundaries of marketing: What needs to be known: SAGE Publications Sage CA: Los Angeles, CA.

[21]. Leonidou, L. C., Palihawadana, D., \& Theodosiou, M. (2011). National export-promotion programs as drivers of organizational resources and capabilities: effects on strategy, competitive advantage, and performance. Journal of International Marketing, 19(2), 1-29.

[22]. Martin, S. L., Javalgi, R. G., \& Cavusgil, E. (2017). Marketing capabilities, positional advantage, and performance of born global firms: Contingent effect of ambidextrous innovation. International business review, 26(3), 527-543.

[23]. Martin, S. L., \& Javalgi, R. R. G. (2016). Entrepreneurial orientation, marketing capabilities and performance: the moderating role of competitive intensity on Latin American International new ventures. Journal of business research, 69(6), 2040-2051.

[24]. Martin, S. L., \& Javalgi, R. R. G. (2019). Explaining performance determinants: A knowledge based view of international new ventures. Journal of Business Research, 101, 615-626. 
[25]. Martin, S. L., Javalgi, R. R. G., \& Ciravegna, L. (2020). Marketing capabilities and international new venture performance: The mediation role of marketing communication and the moderation effect of technological turbulence. Journal of Business Research, 107, 25-37.

[26]. Mashahadi, F., Ahmad, N. H., \& Mohamad, O. (2016). Strategic innovation ambidexterity and the internationalization performance of small and medium enterprises. World Journal of Entrepreneurship, Management and Sustainable Development, 12(2), 161-175.

[27]. Menguc, B., Auh, S., \& Shih, E. (2007). Transformational leadership and market orientation: Implications for the implementation of competitive strategies and business unit performance. Journal of business Research, 60(4), 314-321.

[28]. Moorman, C., \& Day, G. S. (2016). Organizing for marketing excellence. Journal of Marketing, 80(6), 635.

[29]. Morgan, N. A., Feng, H., \& Whitler, K. A. (2018). Marketing capabilities in international marketing. Journal of International Marketing, 26(1), 61-95.

[30]. Morgan, N. A., Katsikeas, C. S., \& Vorhies, D. W. (2012). Export marketing strategy implementation, export marketing capabilities, and export venture performance. Journal of the academy of marketing science, 40(2), 271-289.

[31]. Murray, J. Y., Gao, G. Y., \& Kotabe, M. (2011). Market orientation and performance of export ventures: the process through marketing capabilities and competitive advantages. Journal of the Academy of Marketing Science, 39(2), 252-269.

[32]. Nummela, N., Saarenketo, S., \& Puumalainen, K. (2004). A global mindset - a prerequisite for successful internationalization? Canadian Journal of Administrative Sciences/Revue Canadienne des Sciences de l'Administration, 21(1), 51-64.

[33]. Ren, S., Eisingerich, A. B., \& Tsai, H.-T. (2015). How do marketing, research and development capabilities, and degree of internationalization synergistically affect the innovation performance of small and medium-sized enterprises (SMEs)? A panel data study of Chinese SMEs. International business review, 24(4), 642-651.

[34]. Rennie, M. W. (1993). Born global. The McKinsey Quarterly(4), 45-53.

[35]. Rua, O., França, A., \& Ortiz, R. F. (2018). Key drivers of SMEs export performance: the mediating effect of competitive advantage. Journal of Knowledge Management.

[36]. Spanos, Y. E., \& Lioukas, S. (2001). An examination into the causal logic of rent generation: contrasting Porter's competitive strategy framework and the resource-based perspective. Strategic management journal, 22(10), 907-934.

[37]. Styles, C., \& Ambler, T. (1994). Successful export practice. International Marketing Review.

[38]. Sun, W., Price, J., \& Ding, Y. (2019). The longitudinal effects of internationalization on firm performance: The moderating role of marketing capability. Journal of Business Research, 95, 326-337.

[39]. Tan, Q., \& Sousa, C. M. (2015). Leveraging marketing capabilities into competitive advantage and export performance. International Marketing Review.

[40]. Vorhies, D. W., \& Morgan, N. A. (2005). Benchmarking marketing capabilities for sustainable competitive advantage. Journal of Marketing, 69(1), 80-94.

[41]. Weerawardena, J., \& Mavondo, F. T. (2011). Capabilities, innovation and competitive advantage. Industrial Marketing Management, 40(8), 1220-1223.

[42]. Zeng, S., Xie, X., Tam, C. M., \& Wan, T. (2009). Relationships between business factors and performance in internationalization. Management Decision.

[43]. Zou, S., Fang, E., \& Zhao, S. (2003). The effect of export marketing capabilities on export performance: an investigation of Chinese exporters. Journal of International marketing, 11(4), 32-55. 